\title{
Synchrony of Inflorescence Initiation and Shoot Growth in Selected Protea Cultivars
}

\author{
Audrey I. Gerber, Karen I. Theron, ${ }^{1}$ and Gerard Jacobs ${ }^{2}$ \\ Department of Horticultural Science, University of Stellenbosch, Private Bag X1, Matieland 7602, South \\ Africa
}

\begin{abstract}
AdDitional INDEX wORDs. Proteaceae, budbreak, inflorescence development
Abstract. Protea L. sp. can be assigned to groups according to similar times of flower initiation and harvest. The stages occurring during flower initiation and their synchrony relative to shoot growth were investigated for three cultivars when flower initiation occurred on the spring growth flush. For all three cultivars, the spring flush was preformed and enclosed in the apical bud before spring budbreak. During elongation of the spring flush, the apical meristem produced floral primordia which differentiated into involucral bracts. After completion of the spring flush, meristematic activity continued and produced floral bracts with florets in their axils. The different cultivars were characterized by differences or similarities in the time of budbreak, and the rates of shoot growth, appendage formation, and flower development. Insight into the time of flower initiation relative to vegetative growth could be useful in making management decisions, as well as forming a basis for manipulation of the flowering process.
\end{abstract}

Many genera of the Proteaceae have potential as cut flowers. The main genera under production are Protea L., Leucospermum R. Br., Leucadendron R. Br., Banksia R. Br., Serruria Salisb., and Telopea $\mathrm{R}$. Br. There is little information available regarding flower initiation and development in Proteaceae. In other floriculture crops, e.g., chrysanthemum [Dendranthema $\times$ grandiflora Kitam. (syn. Chrysanthemum $\times$ morifolium Ramat.)] and carnation (Dianthus caryophyllus L.), a knowledge of factors controlling flower initiation has been instrumental in the development of strategies to provide a continuous supply of a high quality product. In order to meet market demands for volume and quality, a fundamental knowledge of the flowering process of Proteaceae is essential.

Short days induce flowering in Leucospermum sp. (Malan and Jacobs, 1990) and Serruria florida Knight (Malan and Brits, 1990). In Leucospermum this information, together with an understanding of correlative phenomena associated with flowering, has lead to the development of disbudding techniques which are used to delay flowering time (Jacobs and Honeyborne, 1978; Jacobs et al., 1986). Studies of Banksia under controlled environmental conditions suggest that flower initiation in $B$. coccinea $R$. $\mathrm{Br}$. is influenced by daylength, and in $B$. hookeriana Meissner by temperature (Rieger and Sedgley, 1996). Protea sp. differ not only in the time of year when anthesis occurs, but certain species, such as $P$. eximia (Salisb. ex Knight) Fourc., can flower at any time of the year. Most species, however, have a flowering time restricted to a particular time of year.

Inflorescence initiation and development of three protea cultivars, 'Carnival' ( $P$. compacta $\mathrm{R}$. Br. $\times P$. neriifolia $\mathrm{R}$. Br.), 'Sylvia' ( $P$. eximia $\times P$. susannae Phill.), and 'Lady Di' $(P$. magnifica Link $\times P$. compacta) were studied. Shoot growth in these cultivars occurs in flushes, and they have different flowering times. Inflorescence formation of 'Carnival' is essentially limited to the spring shoot growth flush when this flush is subtended by one or more previous flushes (Greenfield et al.,

Received for publication 15 Feb. 2000. Accepted for publication 16 Nov. 2000 This paper is a portion of a $\mathrm{PhD}$ dissertation submitted by A.I.G. to the University of Stellenbosch. The cost of publishing this paper was defrayed in part by the payment of page charges. Under postal regulations, this paper therefore must be hereby marked advertisement solely to indicate this fact.

${ }^{1}$ Associate professor.

${ }^{2}$ Professor.
1994). It rarely flowers on the summer flush, which follows the spring flush. Over the course of a year 'Carnival' plants pruned in late winter produce three or four shoot growth flushes before flowering occurs on the spring flush of the following year (Greenfield et al., 1994).

Inflorescence formation of 'Lady Di' is comparable to 'Carnival' in that it is restricted to the spring growth flush subtended by one or more previous flushes (personal observations). 'Lady Di' does not usually produce more than two shoot growth flushes per year and flowers are harvested from May to June. Flowering of 'Sylvia' can occur all year round on shoots composed of two or more shoot growth flushes (personal observations). In this study, we report on the characteristics of the spring flush that subtends an inflorescence; the time of inflorescence initiation; the progression of inflorescence differentiation; and the processes involved in the formation of successive shoot growth flushes in 'Carnival', 'Sylvia' and 'Lady Di'. This information will enhance understanding of the flowering process, contributing to the possibility of manipulating flowering time to suit market demands.

\section{Materials and Methods}

Plant material. Plants of 'Carnival', 'Sylvia', and 'Lady Di' used in this study were grown in commercial plantations in the

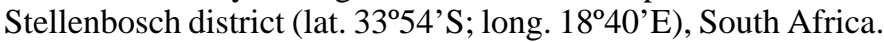
In 1995 'Carnival' and 'Lady Di' plants were 5 years old, and 'Sylvia' plants were 6 years old. For studies of 'Carnival', two separate production blocks of the same age, pruned for biennial bearing, were used; one in the vegetative cycle of biennial bearing, and one in the flowering cycle (Gerber et al., 1995). The plants were spaced $1 \mathrm{~m}$ in the row and $4 \mathrm{~m}$ between rows, clean cultivated and were not fertilized or irrigated. The Stellenbosch climate is Mediterranean, with cool, wet winters (average maximum $17.6{ }^{\circ} \mathrm{C}$ and minimum $8.1{ }^{\circ} \mathrm{C}$ ) and hot, dry summers (average maximum $27.2{ }^{\circ} \mathrm{C}$ and minimum $14.8^{\circ} \mathrm{C}$ ). Annual rainfall is 600 to $700 \mathrm{~mm}$.

SuCCESSIVE SHOOT GROWTH FLUSHES IN 'CARNIVAL'. 'Carnival' plants in the vegetative cycle of biennial bearing (pruned 20 Aug. 1996) were used to study the manner in which shoot growth flushes developed. Pruning consisted of heading back all shoots to leave the basal 15 to $20 \mathrm{~cm}$ portion (bearer), as described previously (Gerber et al., 1995), on which new shoot growth 
originated from axillary buds. At the first sign of budbreak in spring, similar sized bearers were tagged on a number of plants in the commercial plantation. When the first flush was complete, individual shoots of similar size were tagged to further reduce variation, and the production of subsequent summer and Fall growth flushes studied.

$\mathrm{At} \approx 2$-week intervals, starting from bud sprouting in spring (18 Sept. 1996), five previously tagged buds or developing shoots were collected, shoot length measured, and the apical bud dissected using a stereomicroscope. The number of appendages (determined to develop into budscales, transitional leaves or true leaves) were counted. This was continued until all three shoot growth flushes were completed (7 Aug. 1997). To enable comparison of these data with 'Carnival' plants in the reproductive cycle of biennial bearing, the sampling date was also calculated as the number of days from pruning, i.e., the start of shoot growth. At the completion of each growth flush, the number of appendages that constituted the flush became known. This number was subtracted from the total number of appendages present on the shoot and in the apical bud during development, to identify which appendages belonged to the following flush.

APPENDAGE FORMATION DURING THE SPRING GROWTH FLUSH. During winter and before commencement of the spring growth flush in 1996, shoots were tagged on a number of plants in the commercial plantation. Shoots of 'Carnival' and 'Sylvia' were composed of three shoot growth flushes and 'Lady Di', two shoot growth flushes. 'Sylvia' shoots which were likely to flower on the spring flush were selected. At $\approx 2$-week intervals, five previously tagged samples of the apical bud or the developing spring growth flush were collected for dissection under the stereomicroscope. 'Carnival' plants were in the reproductive cycle of biennial bearing (pruned 5 Sept. 1995) and sampling dates were also calculated as the number of days from pruning, i.e., the start of vegetative growth, to enable comparison with shoots on plants in the vegetative cycle. The number of appendages constituting the apical bud and the developing spring growth flush were counted. This continued until completion of elongation of the spring growth flush. After this, it became impossible to count the appendages on the developing inflorescence, due to their small size. It was not possible to distinguish the transition of appendages destined to become leaves or involucral bracts morphologically, during elongation of the spring flush. Since the average number of appendages constituting the spring growth flush was known after completion of the spring growth flush, this number could be subtracted from the total number of appendages present in the developing spring flush and apical meristem, to yield the progression in the formation of involucral primordia. The length of the spring growth flush was also measured.

INFLORESCENCE AND FLOWERING SHOOT CHARACTERISTICS. Five flowering shoots of 'Carnival', composed of the following shoot growth flushes: Spring 1995, Summer 1995, Fall 1996, and Spring 1996, which subtended an inflorescence, were cut from different plants 24 Feb. 1997 (summer). Simi- larly, five flowering shoots of 'Sylvia' and 'Lady Di' were collected 20 Jan. 1997 (summer) and 9 June 1997 (winter), respectively. 'Sylvia' shoots were composed of the inflorescence subtended by the spring shoot growth flush of 1996 and three earlier shoot growth flushes. Shoots of 'Lady Di' were composed of the spring shoot growth flush of 1996, subtending an inflorescence, and the Fall 1996 plus the Spring 1995 shoot growth flushes. The oldest flush of flowering shoots originated from an axillary bud on a bearer.

Shoots were cut at the point of inception and brought into the laboratory. The length of each flush unit of a shoot was measured separately and the number of budscales, transitional leaves, and true leaves were counted. The basal inflorescence diameter was measured and the number of involucral bracts and florets (each subtended by a floral bract) that constituted the inflorescence were counted. The number of involucral bracts includes peduncular bracts because the distinction between the two bract types is subjective and both form part of the floral structure.

INFLORESCENCE DEVELOPMENT. Ten shoots per cultivar were tagged on different plants in the field when the inflorescence bud was $\approx 10 \mathrm{~mm}$ in basal diameter, whereafter the diameter was measured at 2 week intervals. During inflorescence development, samples of apical buds of 'Carnival' were placed in FAA (formaldehyde-acetic acid-50\% ethanol, 1:1:18 by volume). These apical buds were dissected to view the morphological changes

\footnotetext{
Fig. 1. Appendage formation and length of developing growth flushes of Protea 'Carnival' from pruning to anthesis. (A) Number of appendages formed during shoot flush growth, (B) corresponding length of growth flushes, (C) number of appendages in the developing inflorescence and spring flush subtending the inflorescence, and (D) corresponding length of the spring flush subtending the inflorescence. (The vegetative and reproductive cycles are presented in phenological, not chronological, order. To enable comparison between the two cycles the date on the $\mathrm{x}$-axis is also expressed in parenthesis above the axis as the number of days from pruning, i.e., the start of shoot growth). Legend in A applies to $\mathrm{B}$, and the legend in $\mathrm{C}$ applies to $\mathrm{D}$.
}

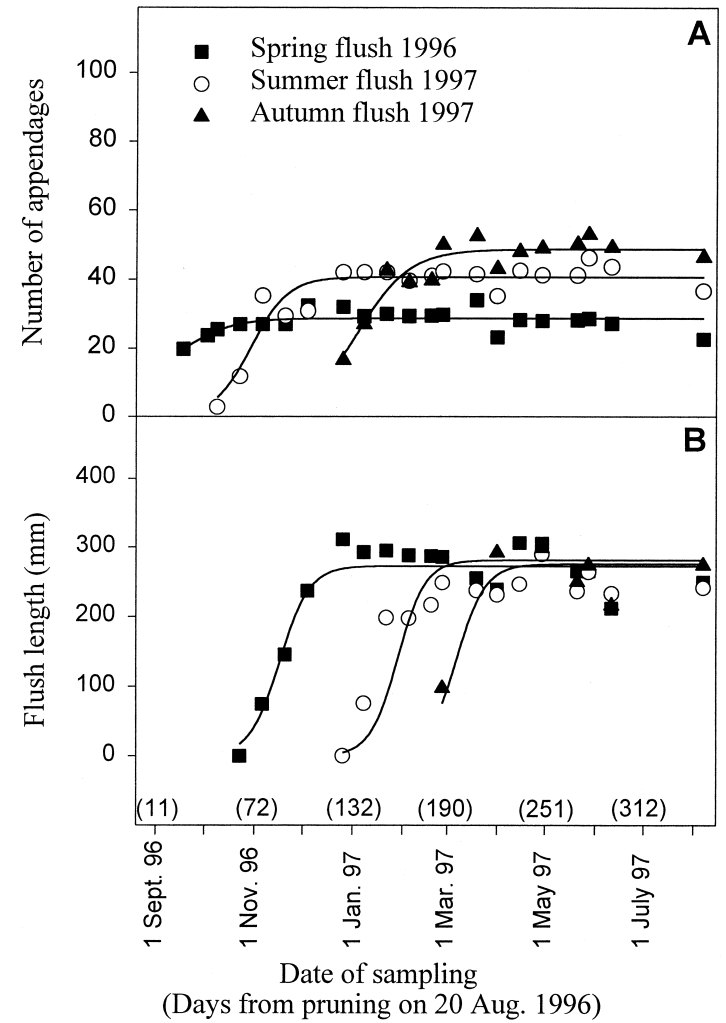

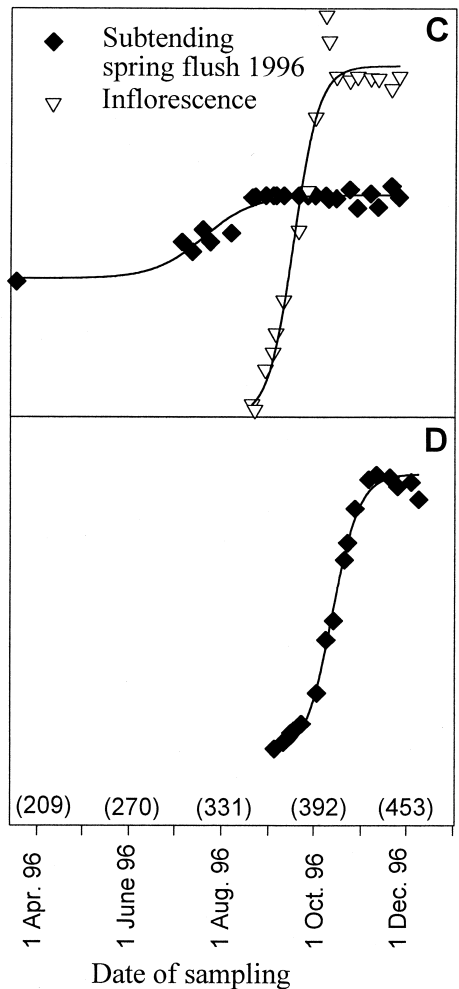

(Days from pruning on 5 Sept. 1995) 
Table 1. Characteristics of the flowering shoot of Protea cultivars at anthesis when the inflorescence is subtended by a spring flush ( $\mathrm{n}=5 \pm 1 \mathrm{SE})$.

\begin{tabular}{|c|c|c|c|c|}
\hline Characteristic & Spring 1995 & Summer 1996 & Fall 1996 & Spring 1996 \\
\hline & \multicolumn{4}{|c|}{ 'Carnival' } \\
\hline Length (mm) & $273 \pm 25.8$ & $239 \pm 30.0$ & $261 \pm 33.1$ & $395 \pm 29.9$ \\
\hline Budscales $^{\mathrm{z}}$ & & $10 \pm 0.9$ & $16 \pm 1.9$ & $19 \pm 1.9$ \\
\hline Transitional leaves & $4 \pm 1.3$ & $6 \pm 0.5$ & $6 \pm 1.0$ & $10 \pm 1.4$ \\
\hline Leaves & $25 \pm 2.6$ & $25 \pm 2.3$ & $26 \pm 2.4$ & $36 \pm 3.2$ \\
\hline \multirow[t]{2}{*}{ Total appendages } & $29 \pm 2.6$ & $41 \pm 2.9$ & $49 \pm 2.6$ & $65 \pm 4.9$ \\
\hline & \multicolumn{4}{|c|}{ 'Lady Di' } \\
\hline Length (mm) & $216 \pm 27.8$ & & $162 \pm 15.0$ & $420 \pm 82.5$ \\
\hline Budscales $^{z}$ & & & $12 \pm 1.0$ & $20 \pm 3.3$ \\
\hline Transitional leaves & $4 \pm 0.9$ & & $5 \pm 0.7$ & $7 \pm 2.3$ \\
\hline Leaves & $21 \pm 2.1$ & & $22 \pm 1.9$ & $47 \pm 8.0$ \\
\hline \multirow[t]{3}{*}{ Total appendages } & $26 \pm 1.3$ & & $39 \pm 2.3$ & $74 \pm 9.4$ \\
\hline & \multicolumn{4}{|c|}{ 'Sylvia' } \\
\hline & Flush $1^{\mathrm{y}}$ & Flush $2^{\mathrm{y}}$ & Flush $3^{y}$ & Spring 1996 \\
\hline Length (mm) & $181 \pm 50.5$ & $187 \pm 34.6$ & $164 \pm 30.7$ & $164 \pm 32.8$ \\
\hline Budscales $^{\mathrm{z}}$ & & $11 \pm 1.5$ & $15 \pm 2.4$ & $28 \pm 5.5$ \\
\hline Transitional leaves & $4 \pm 1.2$ & $3 \pm 0.8$ & $3 \pm 0.8$ & $6 \pm 0.9$ \\
\hline Leaves & $12 \pm 2.7$ & $15 \pm 2.0$ & $17 \pm 2.3$ & $25 \pm 5.3$ \\
\hline Total appendages & $16 \pm 2.7$ & $29 \pm 2.9$ & $35 \pm 3.5$ & $59 \pm 8.0$ \\
\hline
\end{tabular}

${ }^{\mathrm{z}}$ Budscales of the first flush become concealed in the junction between bearer and shoot.

yFlushing is less synchronous in 'Sylvia' and specific seasonal flushes are difficult to identify.

taking place in the bud during inflorescence development, by scanning electron microscope (SEM). After removal from the FAA, the buds were ethanol-dehydrated, critical-point-dried with $\mathrm{CO}_{2}$, and sputter-coated with gold at $1 \mathrm{kV}$ for $5 \mathrm{~min}$ in an ioncoater (Auto 306; Edwards, Crawley, Sussex, United Kingdom). The buds were viewed on a scanning electron microscope (JSM 6100; Joel, Watchmead Garden City, Hertfordshire, United Kingdom) at an accelerating voltage of $5 \mathrm{kV}$. Micrographs were taken with a camera (HR 80018; Joel) using 120 mm, 100 ASA film (AgfaGevaert AG, D-51301 Leverkulsen, Germany).

\section{Results}

SucCessive Shoot growth Flushes in 'CARnival'. Pruning 'Carnival' shoots released rudimentary buds in upper axillary positions on the bearer from correlative inhibition, allowing meristematic activity in the buds to resume. The first visual signs of bud expansion were noticed $29 \mathrm{~d}$ after pruning, on $18 \mathrm{Sept}$. 1996. Bud expansion continued for a further $21 \mathrm{~d}$ before flush extension started in early October. During this $50-\mathrm{d}$ period from pruning, the meristem produced a total number of 28 appendages, which constituted the first (spring) growth flush (Fig. 1A). Only after all the appendages had been produced did the spring flush start elongating.

During elongation of the first spring flush (1996) (Fig. 1B), the meristem produced the elements necessary for the subsequent (summer) flush (Fig. 1A). Almost the full complement of appendages necessary for the summer flush was contained in the apical bud when expansion of the spring flush was complete in early December. A lag of $\approx 2$ weeks separated the end of spring flush growth and the start of enlargement of the terminal bud to produce the summer flush.

The aforementioned developmental pattern was repeated for the fall growth flush. While the summer flush was elongating (Fig. 1B), the meristem formed the appendages that would comprise the fall flush (Fig. 1A). When elongation of the summer flush was complete, the majority of the fall flush appendages had been formed, and there was a lag of 1 week before growth of the fall flush began. Fall flush elongation was accompanied by formation of appendages for the spring flush. When elongation of the fall flush was complete (at the end of April) the apical bud contained $\approx 70 \%$ of the appendages for the second spring flush. Meristematic activity continued through winter to produce the full complement of appendages for the spring flush (Spring 1998, on plants in the reproductive cycle) (Fig. 1C). Before spring budbreak, in early September, the entire spring flush was preformed and enclosed in the apical bud. During spring budbreak,

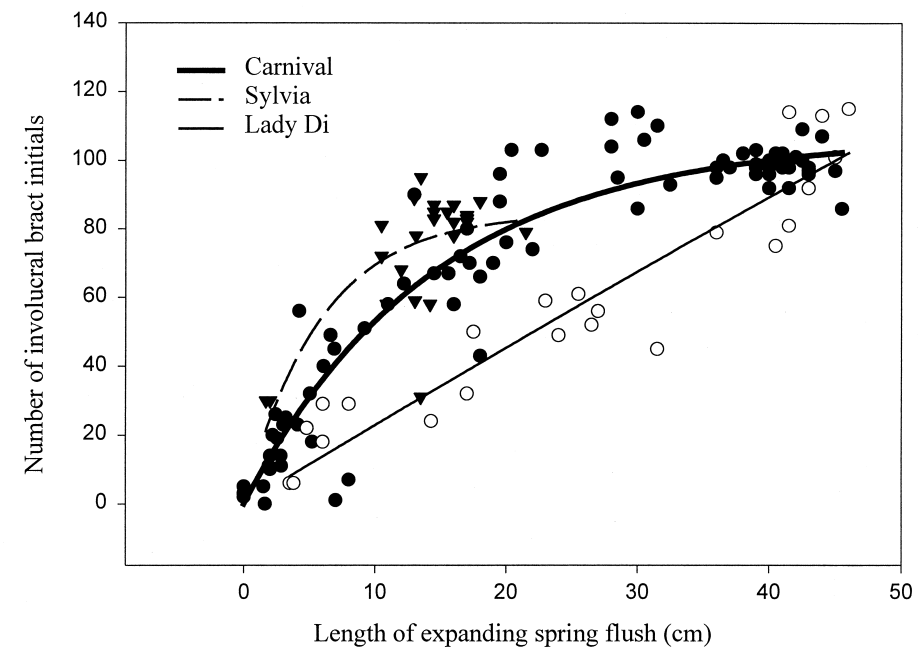

Fig. 2. Appendage formation during elongation of the spring flush which subtends the inflorescence in three Protea cultivars, 'Carnival' (closed circles, $\mathrm{y}=$ $\left.107.020[1-\exp (-0.069 \mathrm{x})], r^{2}=0.907, P<0.0001\right)$, 'Sylvia' (closed triangles, $\mathrm{y}$ $\left.=84.715[1-\exp (-0.172 \mathrm{x})], r^{2}=0.582, P<0.0001\right)$, and 'Lady Di' (open circles, $\left.\mathrm{y}=2.140 \mathrm{x}+3.294, r^{2}=0.895, P<0.0001\right)$ 
Table 2. Characteristics of the inflorescence of Protea cultivars at anthesis when subtended by a spring flush ( $\mathrm{n}=5 \pm 1 \mathrm{SE})$.

\begin{tabular}{lccc}
\hline \hline Characteristic & 'Carnival' & 'Sylvia' & 'Lady Di' \\
\hline Inflorescence diam $(\mathrm{mm})^{\mathrm{z}}$ & $40.5 \pm 5.5$ & $43.8 \pm 2.6$ & $60.5 \pm 3.3$ \\
Involucral bracts $^{\mathrm{y}}$ & $99 \pm 4.9$ & $98 \pm 1.1$ & $127 \pm 5.5$ \\
Florets $^{\mathrm{x}}$ & $232 \pm 10.4$ & $205 \pm 15.3$ & $240 \pm 18.4$
\end{tabular}

${ }^{\mathrm{z}}$ Measured at the widest basal portion.

yIncluding peduncular bracts.

${ }^{\mathrm{x}}$ Each subtended by a floral bract.

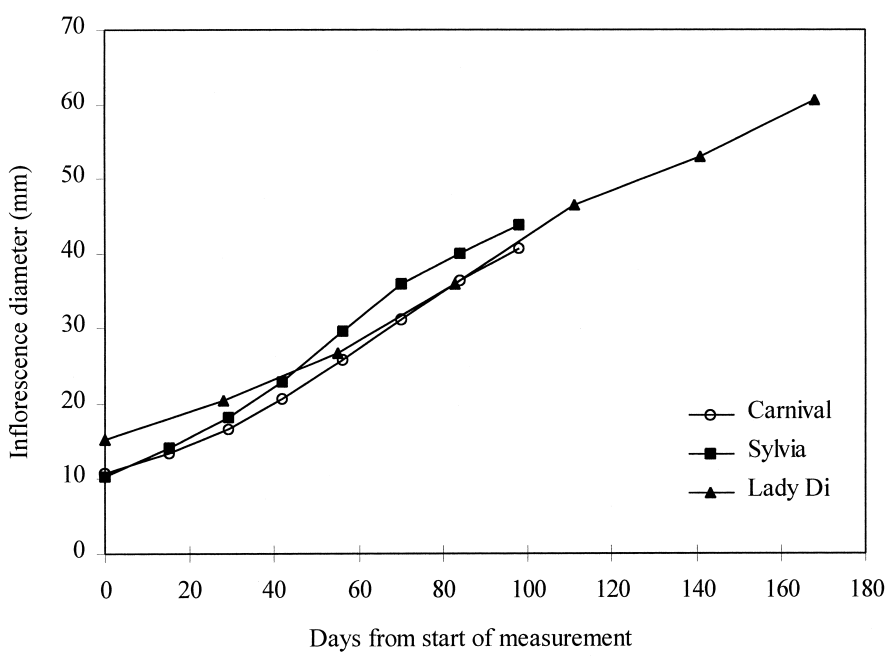

Fig. 3. Basal diameter of inflorescences during development from $10 \mathrm{~mm}$ to anthesis (mean of 10 shoots). In 1997 spring budbreak occurred 18 Aug., and measurement of 'Carnival' and 'Sylvia' started 22 Oct. 1997. In 1996 spring budbreak of 'Lady Di' occurred 16 Oct., and measurement started on 5 Feb. 1997. SE values $(n=10)$ for inflorescence diameter of 'Carnival' $=1.28$, of 'Sylvia' = 1.12, and of 'Lady Di' = 2.06.

before elongation of the spring flush, the preformed leaves in the apical bud differentiated and began development while still enclosed by scalelike bracts surrounding the bud. During subsequent elongation of internodes, leaf development continued.

Neither appendage formation, nor flush elongation occurred at a constant rate (Fig. 1). Extension growth of the flushes of 'Carnival', especially the spring growth flush, was sigmoidal (Fig. 1B and D). Slow rates of growth were apparent at the beginning and end of elongation, with a phase of rapid growth in between.

APPENDAGE FORMATION ONFLOWERING SPRING GROWTHFLUSHES. At the time when terminal budbreak occurred in spring, terminal buds contained $67 \pm 7.8,78 \pm 14.0$ and $66 \pm 3.8$ appendages for 'Carnival', 'Sylvia', and 'Lady Di', respectively. These numbers equalled or exceeded the average final number of appendages that constituted the spring growth flush subtending an inflorescence for the three cultivars (Table 1). The appendages for the spring growth flush were thus preformed before elongation began. Subtracting this number from the total number of appendages present in the developing bud and apical meristem yielded the progression in the formation of involucral bract primordia during spring flush elongation (Fig 1C). It is evident for all three cultivars that the involucral bract primordia were formed during extension growth of the spring shoot growth flush (Fig. 2). The number of appendages present in the apical bud at the time of completion of the spring flush was comparable to the number of involucral bracts present on the mature inflorescence (Table 2).

The relationship between length of the spring flush and num- ber of appendages present in the apical bud of 'Carnival' and 'Sylvia' showed an exponential rise to a maximum (Fig. 2). During the early stages of extension growth, many appendages were formed but fewer formed during the end of elongation of the spring flush. The relationship between length of the spring flush and number of appendages present in the apical bud of 'Lady Di', however, was linear.

INFLORESCENCE AND FLOWERING SHOOT CHARACTERISTICS. The characteristics of flowering shoots of 'Carnival', 'Sylvia', and 'Lady Di' are presented in Tables 1 and 2. The characteristics of the spring shoot growth flush, which subtended the inflorescence, differed from flushes lower down on the stem in the following ways. For all three cultivars, the number of leaves, transitional leaves and budscales, and, therefore, the total number of appendages of the spring flush was greater than preceding flushes (Table 1). The spring flush of 'Carnival' and 'Lady Di', but not 'Sylvia', was longer than preceding flushes. In all three cultivars, starting with the most basal flush, the flushes preceding the spring flush of 1996 progressively contained a greater number of appendages. In the case of 'Carnival' and 'Lady Di' this was due to an increase in the number of budscales, and for 'Sylvia' an increase in both budscales and leaves.

'Lady Di' is a larger inflorescence, as indicated by the basal diameter of $60 \mathrm{~mm}$ compared with 40 and $44 \mathrm{~mm}$ for 'Carnival' and 'Sylvia', respectively, and this greater diameter is reflected by the larger number of involucral bracts (Table 2). The number of florets contained in 'Lady Di' inflorescences was similar to that of 'Carnival', while 'Sylvia' inflorescences contained fewer florets.

INFLORESCENCE DEVELOPMENT. The rate of inflorescence development, as approximated by the increase in diameter, was similar for the three cultivars (Fig. 3). 'Sylvia' and 'Carnival', with similar sized inflorescences, completed development within the same time period. Development of 'Lady Di' infloresences continued for longer and anthesis occurred $\approx 10$ weeks later than 'Carnival' and 'Sylvia'.

The stages of apical meristem development during floral initiation in 'Carnival' are shown in Fig. 4. In the vegetative state, the apical meristem is dome shaped (Fig. 4A), becoming flat and broad for the production of involucral bracts (Fig. 4B). The transition from production of involucral bracts to the production of floral bracts is obvious by a change in phyllotaxy (Fig. 4C). A single floret develops in the axil of each floral bract, with development proceeding acropetally (Fig. 4E). The tips of these florets are hirsute which rapidly obscures development of individual florets (Fig. 4F).

\section{Discussion}

Shoot growth in Protea sp. occurs by elongation of successive growth flushes. With the exception of the flush originating from a rudimentary axillary bud, a flush develops from a preformed shoot in the terminal bud. The leaf primordia in the terminal bud are initiated during elongation of the previous flush and the full complement is present at budbreak. Shoot growth is due to extension of preformed internodes and development of preformed leaf primordia. This is the same pattern of development that describes rhythmic growth in oak (Quercus L. sp.) (Crabbé, 1987)

Most of the appendages for the shoot growth flush developing directly from a rudimentary axillary bud are initiated only after correlative inhibition is removed by pruning. Leaf primordia differentiate after budbreak, but before elongation of the flush. A 


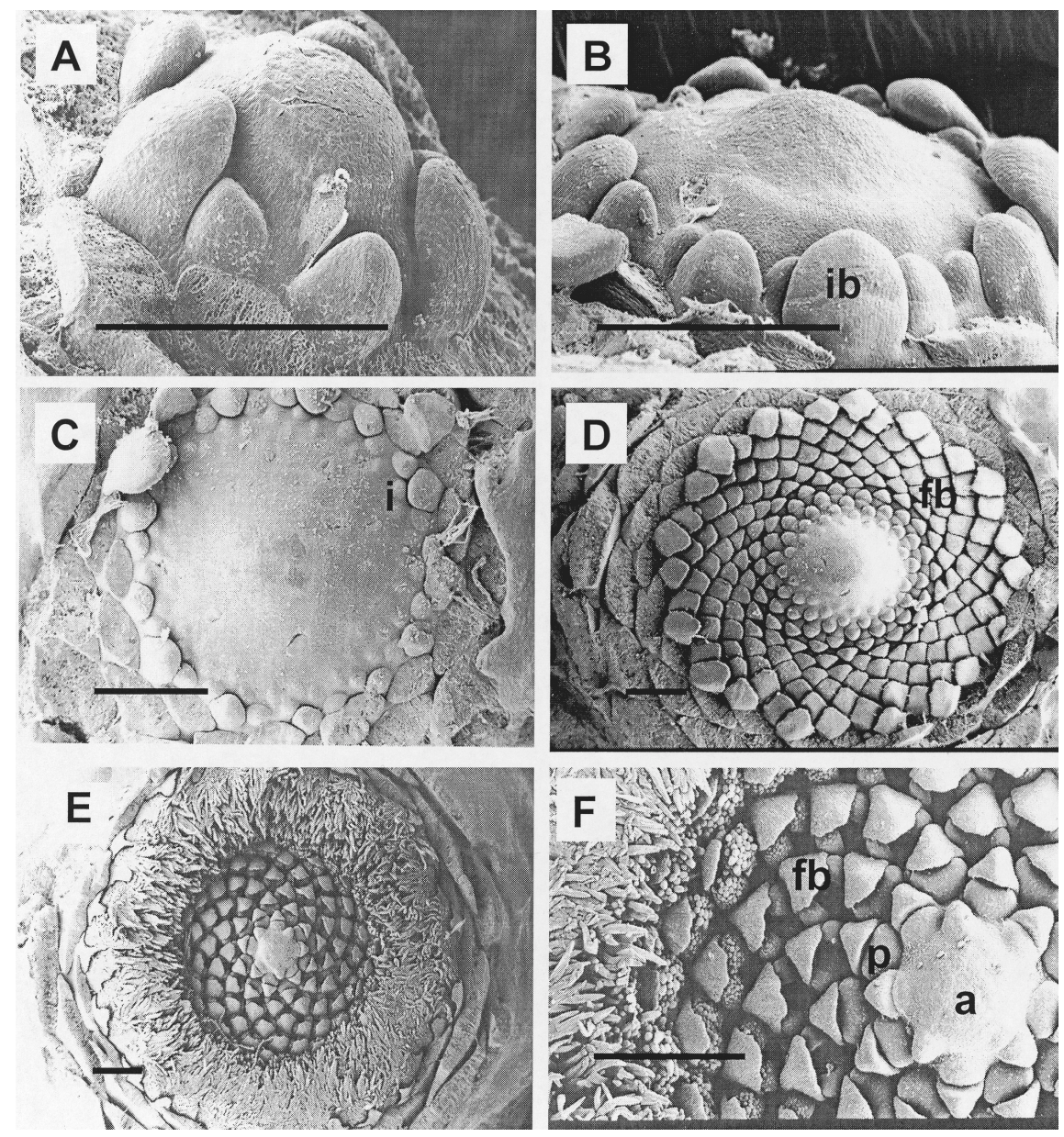

tionship between meristem activity and its fate, although it is apparent from SEM that phyllotaxy does change during the progression from production of leaf primordia through the different stages of inflorescence initiation. The flattening and broadening of the apical meristem prior to production of involucral bracts is similar to meristem changes seen in Leисоspermum during production of peduncular bracts, as is the return to the domed, or conical, state during the initiation of floral bracts (Malan et al., 1994). Floral bracts and individual florets initiate and develop acropetally, as is seen in inflorescence development in Banksia (Fuss and Sedgley, 1990).

With respect to inflorescence initiation on the spring growth flush, it is clear that, for the three cultivars studied, the initial stages of inflorescence initiation and differentiation coincided with elongation of the spring growth flush. Inflorescence development had advanced to the stage where all the involucral bracts had initiated by the time elongation of the spring growth flush was complete, and initiation of floral bracts had begun. Floret initiation and differentiation occurred after completion of the spring growth flush. Dupee and Goodwin (1990) stated that flower initiation in $P$. neriifolia 'Salmon Pink' occurs after spring flush growth in late October or early November (summer), and in P. cynaroides (L.) L. there are two short periods during which flower initiation can occur, i.e., May (fall) and De-

Fig. 4. Changes occurring during floral meristem development in Protea 'Carnival' (scale bar indicates $500 \mu \mathrm{m}$ ). (A) Vegetative meristem prior to flowering is domed and producing leaf primordia. (B) Apical meristem is flat and expanded and producing involucral bracts (ib). (C) Rate of meristem activity increases with rapid production of floral bract initials (i). (D) Later stage of floral bract (fb) initiation, with the surrounding involucral bracts removed. (E) At completion of floral bract initiation the meristem returns to the domed shape. Development of individual florets begins in the outer floral bracts first, which become obscured by hairs on the floret tips. The involucral bracts have been removed. (F) Detail of floret initiation showing gradual stages of development towards the apex (a). A floret primordium (p) develops within each floral bract (fb).

degree of plasticity in the formation of leaf primordia of 'Carnival' is, thus, apparent, where primordia for a specific flush can form during budbreak and during elongation of the previous flush, but the full complement is always present before shoot elongation occurs. Although sequential growth of flushes was not studied for 'Sylvia' and 'Lady Di', the preformed nature of the spring growth flush intimates that the same pattern applies.

The inflorescence bearing spring growth flush differed from other flushes in the number of appendages formed (Table 1). An increase in the number of budscales and transitional leaves with successive growth flushes and a large increase in the number of leaves on the flush subtending the inflorescence were common features for all three cultivars. It is unclear if the increase in appendage number is a prerequisite for flowering. The correlation between a decrease in plastochron and the transition from the vegetative to floral state in apple [Malus sylvestris (L.) Mill. Var domestica (Borkh.) Mansf.] has received much attention (Fulford, 1966; Verheij, 1996). The plastochron was not measured in these investigations and little can be concluded regarding the interrela- cember (summer). In neither instance were the stages of initiation discussed, and the macroscopic appearance of the bud was taken as an indication that initiation had occurred. Heinsohn and Pammenter (1988) noted the presence of visible flower buds in late October on P. neriifolia in South Africa, and concluded that the "flowering signal" was received and acted upon earlier in the growing season. That flower initiation had indeed occurred is unequivocal, yet macroscopic evidence of flowering provides no information as to the time or progression of initiation and development. In $P$. aristata Phill. up to a year can elapse between flower initiation and development, during which axillary shoot growth continues. This is also found, although to a lesser extent, in $P$. repens (L.) L. and P. lanceolata E. Mey. Ex Meisn., and was suggested to be an adaptive mechanism, allowing extra time for shoot diameter growth to occur, both for increased mechanical strength and production of additional conducting tissue to support flower development (Le Maitre and Midgley, 1991). In 'Carnival', 'Sylvia', and 'Lady Di' three phases of inflorescence development can be distinguished: a phase of involucral bract formation, which occurs during extension growth of the shoot flush that subtends the inflorescence; a phase of floret initiation, which occurs after completion of the subtending shoot growth flush; followed directly by an inflorescence enlargement phase.

The characteristics of 'Carnival' and 'Sylvia' inflorescences, when subtended by the spring flush, were similar. Rate of development was similar and they were harvested within the same time period. The start of spring budbreak of 'Lady Di', signalling commencement of inflorescence initiation, was $\approx 8$ weeks later than 'Carnival' and 'Sylvia'. This, together with the longer period 
of inflorescence development, resulted in a much later harvest time (May and June), compared with 'Carnival' and 'Sylvia', which were harvested in February and March, despite also being initiated on the spring flush. In Banksia the 3- to 7-month later flowering time of $B$. hookeriana, compared with B. baxteri $\mathrm{R}$. Br., was due to both a slightly later time of initiation (November to January, compared with September to October, respectively) and a slower initial rate of inflorescence development (Röhl et al., 1994). Floral initiation of both B. coccinea and B. menziesii R. Br. occurred in late spring (October to November), but subsequent inflorescence development was more rapid in $B$. menziesii, leading to earlier anthesis (Fuss and Sedgley, 1990). The reason for later spring budbreak in 'Lady Di' is unclear, but may be due to a photoperiodic requirement which is only fulfilled by the long days occurring after the September equinox (Southern hemisphere). Vegetative growth in Protea 'Ivy' was inhibited under short day conditions in winter and was stimulated by daylength continuation with an artificial light source (unpublished results). Other environmental factors, such as increasing solar radiation and temperature, could also play a role.

In conclusion, three sinks are active during development of a shoot growth flush in Protea sp.: growth of preformed leaves, extension growth of preformed internodes, and formation of new appendages in the apical meristem. The appendages give rise either to new leaves for the next flush of shoot growth, or involucral bracts of the inflorescence. All three cultivars studied had similar strategies of inflorescence initiation and development when borne on the spring flush.

\section{Literature Cited}

Crabbé J. 1987. Aspects particuliers de la morphogenése caulininaires des végétaux ligneux et introduction à leurétude quantitative. Centre d'Etude de la Reproduction Végétale, Brussels, Belgium.

Dupee, S.A. and P.B Goodwin. 1990. Flower initiation in Protea and Telopea. Acta Hort. 264:71-78.

Fulford, R.M. 1966. The morphogenesis of apple buds. III. The inception of flowers. Ann. Bot. 30:207-219.

Fuss, A.M. and M. Sedgley. 1990. Floral initiation and development in relation to the time of flowering in Banksia coccinea R.Br. and B. menziesii R.Br. (Proteaceae). Austral. J. Bot. 38:487-500.

Gerber, A.I., E.J. Greenfield, K.I. Theron, and G. Jacobs. 1995. Pruning of Protea cv. Carnival to optimise economic biomass production. Acta Hort. 387:99-106.

Greenfield, E.J., K.I. Theron, and G. Jacobs. 1994. Effect of pruning on growth and flowering response of Protea cv. Carnival. J. S. Afr. Soc. Hort. Sci. 4:42-46.

Heinsohn, R-D. and N.W. Pammenter. 1988. Seasonality of shoot growth and flowering in the fynbos shrub Protea neriifolia cultivated in a summer rainfall area. S. Afr. J. Bot. 54:440-444.

Jacobs, G. and G.E. Honeyborne. 1978. Delaying the flowering time of Leucospermum cv. Golden Star by deheading. Agroplantae 10:13-15.

Jacobs, G., D.N. Napier, and D.G. Malan. 1986. Prospects of delaying flowering time of Leucospermum. Acta Hort. 185:61-65.

Le Maitre, D.C. and J.J. Midgley. 1991. Allometric relationships between leaf and inflorescence mass in the genus Protea (Proteaceae): An analysis of the exceptions to the rule. Functional Ecol. 5:476-484.

Malan, D.G. and G.J. Brits. 1990. Flower structure and the influence of daylength on flower initiation of Serruria florida Knight (Proteaceae). Acta Hort. 264:87-92.

Malan, D.G., J.G.M. Cutting, and G. Jacobs. 1994. Correlative inhibition of inflorescence development in Leucospermum 'Red Sunset'. J. S. Afr. Soc. Hort. Sci. 4:26-31.

Malan, D.G. and G. Jacobs. 1990. Effect of photoperiod and shoot decapitation on flowering of Leucospermum 'Red Sunset'. J. Amer. Soc. Hort. Sci. 115:131-135.

Rieger, M.A. and M. Sedgley. 1996. Effect of daylength and temperature on flowering of the cut flower species Banksia coccinea and Banksia hookeriana. Austral. J. Expt. Agr. 36:747-753.

Röhl, L.J., A.M. Fuss, J.A. Dhaliwal, M.G. Webb and B.B. Lamont. 1994. Investigation of flowering in Banksia baxteri $\mathrm{R}$. Br. and B. hookeriana Meissner for improving pruning practices. Austral.J.Expt. Agr.34:1209_ 1216.

Verheij, F.A. 1996. Morphological and physiological aspects of the early phases of flower bud formation in apple. PhDdiss. Agr. Univ. Wageningen, The Netherlands. 